\title{
Preparation of canine relaxin by Fmoc-solid phase synthesis and regioselective disulfide bond formation within the $\mathrm{A}$ - and $\mathrm{B}$-chains
}

\author{
Feng Lin', Julien Tailhades' ${ }^{1}$, Linda J. Chan ${ }^{1,2,4}$, Ross A.D. Bathgate ${ }^{1,3}$, Mohammed Akhter Hossain ${ }^{1,2}$ and John D. Wade ${ }^{1,2^{*}}$ \\ *Correspondence: john.wade@florey.edu.au \\ ${ }^{1}$ Florey Institute of Neuroscience and Mental Health, University of Melbourne, Victoria 3010, Australia. \\ ${ }^{2}$ School of Chemistry, University of Melbourne, Victoria 3010, Australia. \\ ${ }^{3}$ Department of Biochemistry and Molecular Biology, University of Melbourne, Victoria 3010, Australia. \\ ${ }^{4}$ Monash Institute of Pharmaceutical Sciences, 381 Royal Parade, Parkville, Victoria 3052, Australia.
}

\begin{abstract}
Background: The chemical synthesis of multi-disulfide bonded heterodimeric peptides such as insulin has long been of significant scientific and commercial interest as well as a major challenge. The development of improved protocols which includes regioselective disulfide bond formation has greatly advanced the capacity to prepare and study insulin-like peptides including canine relaxin, an important regulator of parturition and indicator of canine maternal health.

Methods: Separate, efficient solid phase synthesis of the two constituent chains (24 residue A and 35 residue B) was followed by stepwise formation of each of the three disulfide bonds, one intra within the A-chain and two interchain, by oxidation, thiolysis and iodolysis respectively.

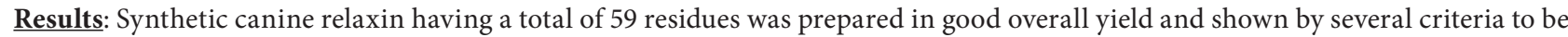
highly purified. The peptide was shown to be less potent than human relaxin ( $\mathrm{H} 2$ relaxin) in binding to and activating the human relaxin receptor, RXFP1, in transfected cells. A circular dichrosim spectroscopic analysis showed that the canine relaxin also possessed significantly less secondary structure compared to $\mathrm{H} 2$ relaxin which may account for its reduced activity.

Conclusions: The synthetic protocols developed in our laboratory enabled the successful preparation of the complex, small insulinlike protein, canine relaxin. This will, in turn, allow a detailed study of both the tertiary conformation of this peptide and its role in canine reproduction.
\end{abstract}

Keywords: Canine relaxin, $\mathrm{H} 2$ relaxin, circular dichroism spectroscopy, regioselective disulfide bond formation, RXFP1 receptor assay, solid phase peptide synthesis

\section{Introduction}

In the human, the insulin/relaxin superfamily comprises of ten members, one of which is relaxin-2 (also known as $\mathrm{H} 2$ relaxin). It consists of two peptide chains, A and B, and contains six conserved cysteine residues which form three disulfide bonds in a pattern that is unique to all the insulin/relaxin superfamily members, one within the A-chain and two others linking the Aand $B$-chains together $[\mathbf{1 , 2}]$. With the exception of the invariant cysteine residues and a glycine within the B-chain, there are significant differences in primary structure between species and also in chain lengths. The A-chain typically has 24 residues but is as short as 20 residues (equine relaxin). The B-chain has greater variations of length and can be as short as 29 residues (also equine) and extending to 33 (guinea pig).

Relaxin is primarily produced by the corpus luteum of the ovary and/or placenta of pregnancy in most mammals where it exerts multiple essential actions on the female reproductive tract to support pregnancy, facilitate delivery and prepare the mammary glands for lactation [3]. More recently, our group and others have shown that locally produced relaxin has much wider actions, including roles in the cardiovascular $[4,5]$ and central nervous systems $[6,7]$ and an essential role in collagen turnover [8]. These actions of relaxin are mediated via a leucine-rich repeat-containing G-protein coupled receptor, known as LGR7 [9], which has more recently been re-named relaxin family peptide 1 (RXFP1) receptor [10]. $\mathrm{H} 2$ relaxin (also commercially named serelaxin) has recently passed a successful Phase III clinical trial for the treatment of acute heart failure due to its potent vasodilatory and cardioprotective properties [11].

Canine relaxin is of particular interest both structurally and biologically. Its isolation from pregnant dog ovaries and subsequent chemical characterization showed it to be one of the largest mammalian relaxins and has a 24 residue $A$-chain and 35 residue B-chain (Figure 1) [12]. It has been extensively studied for its roles in the dog, particularly during pregnancy due to it being a multiple birth mammal [13-15]. A homologous radioimmunoassay has been developed against synthetic canine relaxin and shown to be able to detect as little as $0.19 \mathrm{ng}$ of relaxin [16]. It has formed the basis of a commercially available relaxin assay (ReproCHEK ${ }^{\mathrm{TM}}$ ) which provides a sensitive and accurate diagnosis of pregnancy in the domestic dog and which circumvents the need for specialized equipment and experienced personnel. The same assay has been shown to be effective in wild wolves, coyotes and, curiously, in domestic cats [17-19]. 


\section{D-N-Y-I-K-M-S-D-K-C-C-N-V-G-C-T-R-R-E-L-A-S-R-C}

T-D-D-K-K-L-K-A-C-G-R-D-Y-V-R-L-Q-I-E-V-C-G-S-S-W-W-G-R-K-A-G-Q-L-R-E

Figure 1. The primary structure of canine relaxin.

A.

SH SH

D-N-Y-I-K-M-S-D-K-C-C-N-V-G-C-T-R-R-E-L-A-S-R-C

\begin{tabular}{l|l} 
I & A-chain \\
Acm
\end{tabular}

Oxidation

DPDS

D-N-Y-I-K-M-S-D-K-C-C-N-V-G-C-T-R-R-E-L-A-S-R-C

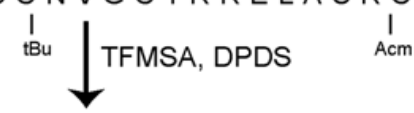

D-N-Y-I-K-M-S-D-K-C-C-N-V-G-C-T-R-R-E-L-A-S-R-C

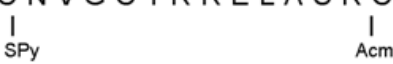

$\underset{\mathrm{SH}}{\mathrm{Acm}}$

T-D-D-K-K-L-K-A-C-G-R-D-Y-V-R-L-Q-I-E-V-C-G-S-S-W-W-G-R-K-A-G-Q-L-R-E

Thiolysis

B-chain

D-N-Y-I-K-M-S-D-K-C-C-N-V-G-C-T-R-R-E-L-A-S-R-C

T-D-D-K-K-L-K-A-C-G-R-D-Y-V-R-L-Q-I-E-V-C-G-S-S-W-W-G-R-K-A-G-Q-L-R-E

$\downarrow \mathrm{I}_{2}$ oxidation

D-N-Y-I-K-M-S-D-K-C-C-N-V-G-C-T-R-R-E-L-A-S-R-C

T-D-D-K-K-L-K-A-C-G-R-D-Y-V-R-L-Q-I-E-V-C-G-S-S-W-W-G-R-K-A-G-Q-L-R-E

Canine relaxin

B.

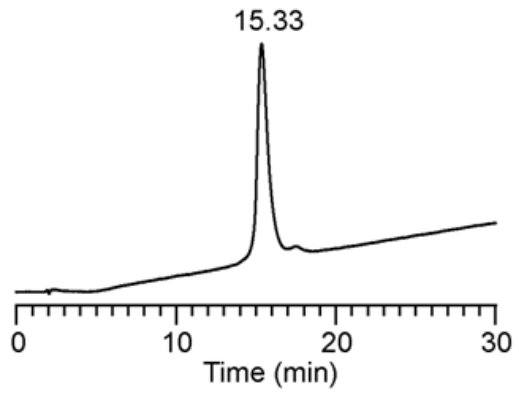

C.

6814.503

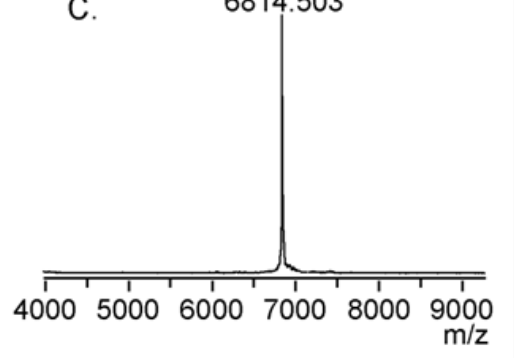

Figure 2. A. Scheme for chemical synthesis of canine relaxin.

B. RP-HPLC (gradient 10-40\% acetonitrile containing 0.1\% TFA over 30 mins, $214 \mathrm{~nm}$ detection). C. MALDI-TOF MS of purified synthetic canine relaxin. Theoretical m/z 6,813.9 $[\mathrm{M}+\mathrm{H}]+$; calcd. 6,814.5. 
Lin et al. Biochemical Compounds 2013,

The chemical synthesis of canine relaxin was previously reported nearly 20 years ago [16]. It used a combination of the older Boc- and now predominantly employed Fmoc-solid phase synthesis chemistry for the separate preparation of the two S-regioselectively protected chains followed by a four step process of sequential disulfide bond formation, chain linkage and selective $N$ (indole)-deprotection [20]. Overall yield of purified canine relaxin was $5 \%$. It was shown to be fully biologically active in inducing relaxation of the mouse interpubic ligaments in vivo. We sought to determine if the synthesis of canine relaxin could be improved using a simpler protocol that has been developed in our laboratory (Figure 2A) [21] and which wholly employs the more mild Fmoc-based synthesis chemistry without the need for additional postcombination deprotection. We also undertook to compare the secondary structure of the peptide with $\mathrm{H} 2$ relaxin as well as by the more sensitive in vitro relaxin receptor binding and activation assays.

\section{Materials and methods}

All amino acid derivatives were purchased from GL Biochem (Shanghai, China) and PEG-polystyrene solid supports from Applied Biosystems Inc (Melbourne, Australia). H2 relaxin was a gift from Corthera/Novartis Inc (San Francisco, USA).

\section{Solid phase peptide synthesis}

This was carried out as previously described [21,22]. For canine relaxin bearing C-terminal acid on its two chains, synthesis of the chains was carried out using appropriately Fmoc-amino acid-preloaded hydroxymethylphenoxyacetyl-derivatised PEG-polystyrene. HCTU-activated Fmoc-amino acids were used throughout. Amino acid side chain protection was afforded by the following: Arg, Pbf; Asn and Gln, Trt; Asp and Glu, O-Bu'; His, Trt; Lys, Boc; Ser and Thr, But. For the A-chain peptide, S-protection was afforded by $\operatorname{Trt}\left(\mathrm{Cys}^{10,15}\right), \mathrm{Acm}\left(\mathrm{Cys}^{24}\right)$ and $\mathrm{Bu}^{\mathrm{t}}\left(\mathrm{Cys}^{11}\right)$. For the B-chain, $\mathrm{Trt}\left(\mathrm{Cys}^{9}\right)$ and $\mathrm{Acm}\left(\mathrm{Cys}^{21}\right)$ were used. No repeat couplings were carried out. $\mathrm{N}^{\mathrm{a}}-\mathrm{Fmoc}$ deprotection was with $20 \%$ piperidine in DMF. Assembly of both the A- and B-chain peptides commenced on $0.2 \mathrm{mmol}$ scales respectively using a 4 -fold excess of activated amino acid and 30 min coupling times. After acylation and deprotection of the final residues, cleavage from the solid supports and side chain deprotection was achieved by a 2.5 -h treatment of the two separate peptide-resins with trifluoroacetic acid (TFA) and, for the B-chain, in the presence of phenol, thioanisole, ethanedithiol and water $(82.5 / 5 / 5 / 2.5 / 5, \mathrm{v} / \mathrm{v})$ with a few drops triethylsilane (TES). For the A-chain, cleavage was effected with TFA in the presence of ethanedithiol, water and TES (95/2/2/1) and isolation of the crude peptide was as previously described [23]. The resulting crude peptides were subjected to preparative reversed-phase high performance liquid chromatography (RP-HPLC) on a Vydac C4 column (Hesperia, USA) using a $1 \% /$ min gradient of $\mathrm{CH}_{3} \mathrm{CN}$ in $0.1 \%$ aqueous TFA.

A-chain intramolecular disulfide oxidation - Crude cleaved
[Cys ${ }^{10,15}$ (S-thiol), Cys ${ }^{11}$ (But), Cys $\left.{ }^{24}(\mathrm{Acm})\right]$ A-chain (658 mgs, 222 $\mu \mathrm{mol})$ was dissolved in $\mathrm{H}_{2} \mathrm{O}(800 \mathrm{ml})$ and to this was added 1 $\mathrm{mM}$ 2-dipyridyl disulfide (DPDS) in $\mathrm{MeOH}(100 \mathrm{~mL}, 100 \mu \mathrm{mol})$ (Figure 2A). Oxidation was complete after $2 \mathrm{~h}$ as monitored by analytical RP-HPLC. The peptide isolated by preparative RP-HPLC and subsequent freeze drying to give $392.0 \mathrm{mgs}$ (59.6\%) of purified [Cys $\left.{ }^{11}(\mathrm{Acm}), \mathrm{Cys}^{24}(\mathrm{But})\right]-\mathrm{A}$-chain.

$\left[C^{11}{ }^{11}(P y r), C y s^{24}(A c m)\right] A$-chain - Intramolecular disulfide bonded [Cys ${ }^{11}$ (But), Cys $\left.{ }^{24}(\mathrm{Acm})\right]$-A-chain $(223.7 \mathrm{mg}, 76 \mu \mathrm{mol})$ was converted to the Cys ${ }^{11} \mathrm{~S}$-pyridinyl form by treatment with DPDS (Figure 2A) in neat TFA ( $5.0 \mathrm{~mL})$ containing thioanisole $(0.5 \mathrm{ml})$ chilled to $\leq 0^{\circ} \mathrm{C} .5 .0 \mathrm{~mL}$ TFMSA/TFA $(1: 5 \mathrm{v} / \mathrm{v})$ was added and stirred for 20-30 mins maintaining the temperature at or below $0^{\circ} \mathrm{C}$. The peptide was then precipitated in ether and the pellet suspended in $6 \mathrm{M} \mathrm{GdHCl}$ for purification. The target peptide was isolated by preparative RP-HPLC to give $164.2 \mathrm{mgs}(72.5 \%)$.

Combination of $\left[\mathrm{Cys}^{11}(\mathrm{SPy}), \mathrm{Cys}^{24}(\mathrm{Acm})\right]$ A-chain with [Cys ${ }^{9}(\mathrm{~S}-$ thiol), Cys $\left.\mathrm{s}^{21}(\mathrm{Acm})\right] \mathrm{B}$-chain - A-chain peptide (164.0 mgs, 54.8 umol) was dissolved in $8 \mathrm{M} \mathrm{GdHCl}(8 \mathrm{~mL})$ and added to purified B-chain (133.8 mg, $32.4 \mu \mathrm{mol})$ in the same buffer $(8 \mathrm{~mL}$ ) (Figure 2A). The mixture was stirred vigorously at room temperature or $37^{\circ} \mathrm{C}$ for each buffer respectively, and reaction monitored by analytical RP-HPLC. After 30 mins (or $24 \mathrm{~h}$ if using the $\mathrm{GdHCl}$ buffer), the reaction was terminated by addition of glacial acetic acid, and the target product isolated by preparative RP-HPLC to give $131.3 \mathrm{mg}$ (58.3\%).

The final disulfide bond formation - The $\left[\mathrm{Cys}^{24}(\mathrm{Acm})\right] \mathrm{A}$-chain/ [Cys ${ }^{21}(\mathrm{Acm}) \mathrm{B}$-chain] $(131.0 \mathrm{mg}, 18.8 \mu \mathrm{mol})$ was dissolved in glacial acetic acid $(136 \mathrm{~mL})$ and $80 \mathrm{mM} \mathrm{HCl}(13 \mathrm{~mL})$ and to this was added dropwise $113 \mathrm{~mL}$ of $20 \mathrm{mM}$ iodine/acetic acid $(2.3 \mathrm{~mol}$ ) (Figure $2 \mathrm{~A})$. After $1 \mathrm{~h}$, the reaction was stopped by addition of $113 \mathrm{~mL}$ of $20 \mathrm{mM}$ ascorbic acid. Preparative RP-HPLC, as described above, was then used to isolate and purify the product $13.8 \mathrm{mg}(10.8 \%)$, yield $6.3 \%$ overall relative to starting purified B-chain.

\section{Peptide characterization}

The purity of the synthetic peptide was assessed by analytical RP-HPLC on a Vydac C4 column (pore size $300 \AA$, particle size $5 \mu \mathrm{m}, 4.6 \times 250 \mathrm{~mm}$ ) using a gradient of acetonitrile in $0.1 \%$ aqueous trifluoroacetic acid. The product was confirmed by MALDI-TOF mass spectrometry using a Bruker Autoflex II instrument (Bremen, Germany) in the linear mode at $19.5 \mathrm{kV}$. The peptide was quantitated by amino acid analysis of a $24 \mathrm{~h}$ acid hydrolysate using a Shimadzu microbore RP-HPLC system. Circular dichroism (CD) spectroscopy was carried out on an Applied Photophysics Chirascan Plus instrument (Leatherhead, UK) using the following settings: wavelength range 195 to $250 \mathrm{~nm}$, scanning speed $50 \mathrm{~nm} / \mathrm{min}$, bandwidth $0.1 \mathrm{~nm}$, cell length $1 \mathrm{~mm}$ at room temperature. The peptide samples were prepared at $0.3 \mu \mathrm{g} / \mu \mathrm{l}$ in phosphate buffered saline (PBS: 20 $\mathrm{mM}$ potassium phosphate buffer with $137 \mathrm{mM} \mathrm{NaCl} \mathrm{pH} \mathrm{7.4).}$ The raw data from the spectra in millidegree of ellipticity $(\theta)$ 
Lin et al. Biochemical Compounds 2013,

were converted to mean residual weight ellipticity (MRE) [24].

\section{Ligand binding assay}

Human embryonic kidney (HEK)-293T cells stably transfected with RXFP1 were grown in RPMI-1640 media (Sigma, Australia) supplemented with $10 \%$ fetal calf serum (FCS), $100 \mu \mathrm{g} / \mathrm{ml}$ penicillin, $100 \mu \mathrm{g} / \mathrm{ml}$ streptomycin and $2 \mathrm{mM} \mathrm{L-glutamine}$ and plated into 24 well poly-L-lysine coated plates for whole cell binding assays. Competition binding experiments were performed with europium-labelled $\mathrm{H} 2$ relaxin [25] in the absence or presence of increasing concentrations of unlabeled peptides. Non-specific binding was determined by addition of $500 \mathrm{nM} \mathrm{H} 2$ relaxin. All data are presented as the mean \pm S.E.M. of the percentage of the specific binding of triplicate wells, repeated in at least three separate experiments, and curves fitted using one-site binding curves in GraphPad Prism 5 (GraphPad Software). Statistical differences in plC50 values were analysed using one-way ANOVA coupled to a Newman Keul's multiple comparison test for multiple group comparisons in GraphPad Prism 5.

\section{Functional cAMP assay}

The influence of the various ligands on cAMP signalling in cells expressing RXFP receptors was assessed using a cAMP reporter gene assay as previously described [26]. Briefly, HEK-293T cells in 96 well plates were co-transfected with either RXFP1 and a pCRE- $\beta$-galactosidase reporter plasmid. 24 hours later cotransfected cells were treated with increasing concentrations of canine relaxin in parallel to $10 \mathrm{nM}$ of $\mathrm{H} 2$ relaxin for RXFP1 transfected cells respectively. After 6 hours, the cell media was aspirated and the cells frozen at $-80^{\circ} \mathrm{C}$ overnight. The amount of cAMP-driven $\beta$-galactosidase expression in each well was determined as previously described [26]. Ligand induced stimulation of cAMP was expressed as a percentage of the maximum $\mathrm{H} 2$ relaxin response. Data points were measured in triplicate and each experiment was repeated at least three times. Statistical differences in $\mathrm{pEC} 50$ values were analysed using one-way ANOVA coupled to a Newman Keul's multiple comparison test for multiple group comparisons in GraphPad Prism 5.

\section{Results and discussion}

The chemical synthesis of a heterodimeric two-chain, three disulfide linked peptide remains a formidable undertaking and has been the subject of many attempts to both optimize and simplify, most recently by way of one-pot processes $[27,28]$. Our approach of using efficient Fmoc-solid phase synthesis of suitably S-protected A- and B-chains followed by stepwise formation of the three disulfides has proven to be highly effective and robust with many assemblies of insulin-like peptides successfully accomplished $[21,22,29-$ 33]. In order to acquire sufficient quantities of canine relaxin to undertake detailed structural and biological studies, we employed our approach (Figure 2A) and subsequently obtained highly purified peptide (Figures $2 \mathrm{~B}$ and $\mathbf{2 C}$ ) in overall yield of more than $6 \%$ relative to the starting crude B-chain. An early assembly reported by others using both Boc- and Fmoc-chemistry, regioselective disulfide bond formation and one additional work-up step provided the peptide in an also good $5 \%$ yield [16]. In our case, despite the length and complexity of the two chains (in particular, the B-chain), use of low-loading hydrophilic solid supports led to their straight forward assemblies [34]. Our experience is that the greatest losses stemmed not from the syntheses of the respective chains or the individual disulfide bond forming steps but from the intermediate HPLC purifications, particularly of the B-chain alone which is poorly soluble.

The synthetic canine relaxin was evaluated for its propensity to bind to and activate human RXFP1 receptor that was overexpressed in HEK cells. As shown in Figure 3, the peptide both strongly binds to (Figure $3 \mathbf{A}$ ) and activates (Figure $3 \mathbf{B}$ ) the receptor although the affinity $(\mathrm{plC} 50=8.31 \pm 0.03 ; \mathrm{p}<0.01$ vs $\mathrm{H} 2$ relaxin, plC50 $=9.08 \pm 0.07$ ) and activity ( $\mathrm{pEC} 50=9.61 \pm 0.03$; $\mathrm{p}<0.05$ vs $\mathrm{H} 2$ relaxin, $\mathrm{pEC} 50=10.30 \pm 0.04$ ) of the peptide is significantly lower compared with $\mathrm{H} 2$ relaxin. Importantly, the activity decrease matched the decreased affinity and is likely the result of species differences in the ligand receptor pairing. Notably, mouse relaxin has a lower affinity for, and activity at, human RXFP1 than its native mouse RXFP1 receptor [22]. The peptide was then assessed for secondary structural conformation using CD spectroscopy (Figure 4). $\mathrm{H} 2$ relaxin exhibits a CD spectrum typical of predominantly a-helical peptides in aqueous solutions characterized by a strong negative band at $208 \mathrm{~nm}$ and a weaker negative band at 222 $\mathrm{nm}$. The calculated helix content is around 39\% (based on the $222 \mathrm{~nm}$ band [35]). In contrast, the canine analogue shows a significantly reduced a-helix structure. The dominant band is blueshifted to $204 \mathrm{~nm}$ and the curve intensity is dramatically reduced. The spectrum resembles those of type C CD curves, representing a series of type I (III) $\beta$-turns or 3-10 helices. The calculated a-helix content drops below $20 \%$. This significantly reduced secondary structure may also be a contributory factor towards the reduced bioactivity results. It is noteworthy, however, that synthetic equine relaxin, which contains just 48 residues, possesses a similarly reduced overall a-helical content whilst being equipotent to $\mathrm{H} 2$ relaxin in binding to human RXFP1 [21]. It is important to note that the sequence difference in overlapping primary structures between the canine and $\mathrm{H} 2$ relaxin is about $55 \%$, sufficient perhaps to also contribute to the observed difference in activity. Nevertheless, the successful acquisition of the complex canine peptide will now allow us to both obtain its tertiary structure via NMR spectroscopy and more thoroughly study its biochemistry and physiology in the canine.

\section{Conclusions}

Canine relaxin, one of the largest native relaxins with 59 residues, was successfully chemically prepared in good overall 
Lin et al. Biochemical Compounds 2013,

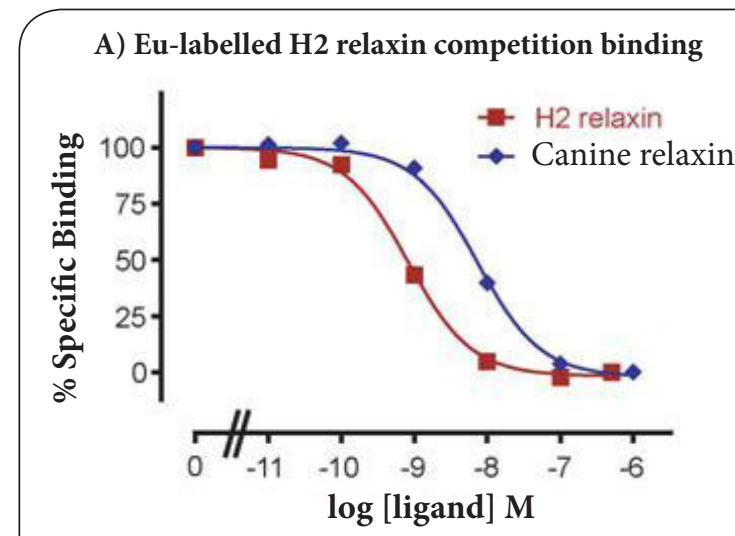

B) cAMP activity

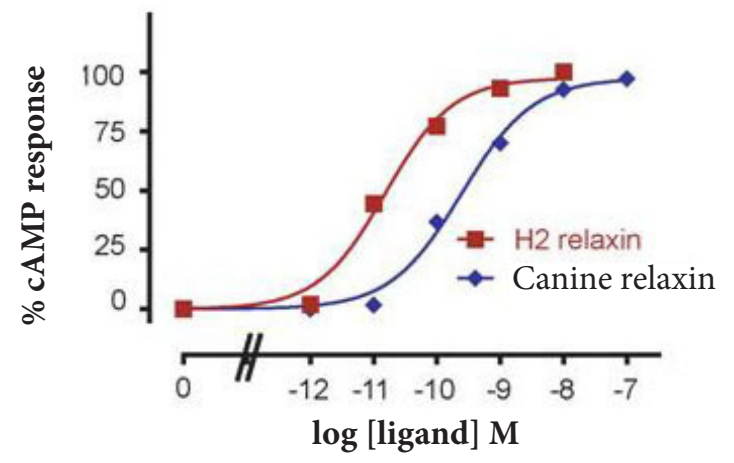

Figure 3. Activity of canine relaxin at RXFP1. A. Competition binding of canine relaxin or $\mathrm{H} 2$ relaxin with europium-labeled $\mathrm{H} 2$ relaxin on HEK293T cells stably expressing RXFP1. Data are expressed as percentage of specific binding and are pooled data from at least three experiments performed in triplicate.

B. cAMP activity in HEK293T cells stably expressing RXFP1 using a pCRE- $\beta$-galactosidase reporter gene system. Data are expressed as percentage of maximum $\mathrm{H} 2$ relaxin stimulated response and are pooled data from at least three experiments performed in triplicate.

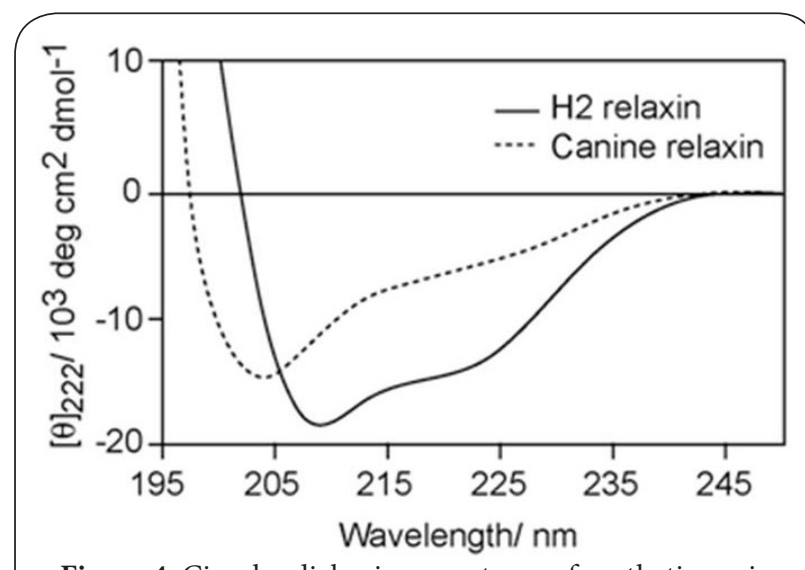

Figure 4. Circular dichroism spectrum of synthetic canine relaxin compared with $\mathrm{H} 2$ relaxin. $\mathrm{CD}$ was performed in $20 \mathrm{mM}$ phosphate buffer at $\mathrm{pH}$ 7.4. yield by a combination of efficient solid phase synthesis of the individual A- and B-chains followed by regioselective disulfide bond formation. The resulting complex peptide that contains three insulin-like disulfide bonds was shown by MALDI-TOF MS and RP-HPLC to be highly purified and to possess modest a-helical structure as assessed by CD spectroscopy. In in vitro activity assays using cells expressing the human relaxin RXFP1 receptor and CD study, synthetic canine relaxin was shown to be less potent and less structured compared with $\mathrm{H} 2$ relaxin.

\section{Competing interests}

The authors declare that they have no competing interests.

\section{Authors' contributions}

\begin{tabular}{|l|c|c|c|c|c|c|}
\hline Authors' contributions & JW & MAH & FL & LJC & JT & RADB \\
\hline Research concept and design & $\sqrt{ }$ & $\sqrt{ }$ & -- & -- & -- & -- \\
\hline Collection and/or assembly of data & $\sqrt{ }$ & $\sqrt{ }$ & -- & -- & -- & -- \\
\hline Data analysis and interpretation & $\sqrt{ }$ & $\sqrt{ }$ & $\sqrt{ }$ & $\sqrt{ }$ & -- & -- \\
\hline Writing the article & $\sqrt{ }$ & $\sqrt{ }$ & -- & -- & $\sqrt{ }$ & $\sqrt{ }$ \\
\hline Critical revision of the article & -- & -- & -- & -- & -- & -- \\
\hline Final approval of article & $\sqrt{ }$ & $\sqrt{ }$ & $\sqrt{ }$ & $\sqrt{ }$ & $\sqrt{ }$ & $\sqrt{ }$ \\
\hline Statistical analysis & -- & -- & -- & -- & -- & -- \\
\hline CD spectral studies & -- & -- & -- & -- & $\sqrt{ }$ & -- \\
\hline
\end{tabular}

\section{Acknowledgement and funding}

This research was partially funded by NHMRC (Australia) project grants 508995, and 1023078 to JDW, MAH and RADB. We are grateful to Tania Ferraro and Sharon Layfield for assistance with biochemical assays. MAH was the recipient of a Florey Foundation Fellowship, and RADB and JDW are NHMRC (Australia) Research Fellows. Research at the Florey Institute of Neuroscience and Mental Health is supported by the Victorian Government Operational Infrastructure Support Program.

\section{Publication history}

Senior Editor: John S. McMurray, University of Texas, USA. Received: 12-Aug-2013 Revised: 30-Aug-2013

Accepted: 02-Sep-2013 Published: 12-Sep-2013

\section{References}

1. Shabanpoor F, Separovic $F$ and Wade JD. The human insulin superfamily of polypeptide hormones. Vitam Horm. 2009; 80:1-31. | Article | PubMed

2. Bathgate RA, Halls ML, van der Westhuizen ET, Callander GE, Kocan M and Summers RJ. Relaxin family peptides and their receptors. Physiol Rev. 2013; 93:405-80. | Article | PubMed

3. Sherwood OD. Relaxin's physiological roles and other diverse actions. Endocr Rev. 2004; 25:205-34. | Article | PubMed

4. Samuel CS, Du XJ, Bathgate RA and Summers RJ. 'Relaxin' the stiffened heart and arteries: the therapeutic potential for relaxin in the treatment of cardiovascular disease. Pharmacol Ther. 2006; 112:529-52. | Article | PubMed

5. Perna AM, Masini E, Nistri S, Briganti V, Chiappini L, Stefano P, Bigazzi $M$, Pieroni C, Bani Sacchi T and Bani D. Novel drug development opportunity for relaxin in acute myocardial infarction: evidences from a swine model. FASEB J. 2005; 19:1525-7. | Article | PubMed

6. McKinley MJ, Cairns MJ, Denton DA, Egan G, Mathai ML, Uschakov A, Wade JD, Weisinger RS and Oldfield BJ. Physiological and 
Lin et al. Biochemical Compounds 2013,

pathophysiological influences on thirst. Physiol Behav. 2004; 81:795803. | Article | PubMed

7. Nistri $S$ and Bani D. Relaxin in vascular physiology and pathophysiology: possible implications in ischemic brain disease. Curr Neurovasc Res. 2005; 2:225-3. | Article | PubMed

8. Samuel CS. Relaxin: antifibrotic properties and effects in models of disease. Clin Med Res. 2005; 3:241-9. | Article | PubMed Abstract | PubMed Full Text

9. Hsu SY, Nakabayashi K, Nishi S, Kumagai J, Kudo M, Sherwood OD and Hsueh AJ. Activation of orphan receptors by the hormone relaxin. Science. 2002; 295:671-4. | Article | PubMed

10. Bathgate RA, Ivell R, Sanborn BM, Sherwood OD and Summers RJ. International Union of Pharmacology LVII: recommendations for the nomenclature of receptors for relaxin family peptides. Pharmacol Rev. 2006; 58:7-31. | Article | PubMed

11. Teerlink JR, Cotter G, Davison BA, Felker GM, Filippatos G, Greenberg BH, Ponikowski P, Unemori E, Voors AA, Adams KF, Jr., Dorobantu MI, Grinfeld LR, Jondeau G, Marmor A, Masip J, Pang PS, Werdan K, Teichman SL, Trapani A, Bush CA, Saini R, Schumacher C, Severin TM and Metra M. Serelaxin, recombinant human relaxin-2, for treatment of acute heart failure (RELAX-AHF): a randomised, placebo-controlled trial. Lancet. 2013; 381:29-39. | Article | PubMed

12. Stewart DR, Henzel WJ and Vandlen R. Purification and sequence determination of canine relaxin. J Protein Chem. 1992; 11:247-53. | Article | PubMed

13. Steinetz BG, Goldsmith LT and Lust G. Plasma relaxin levels in pregnant and lactating dogs. Biol Reprod. 1987; 37:719-25. | Article | PubMed

14. Steinetz BG, Goldsmith LT, Harvey HJ and Lust G. Serum relaxin and progesterone concentrations in pregnant, pseudopregnant, and ovariectomized, progestin-treated pregnant bitches: detection of relaxin as a marker of pregnancy. Am J Vet Res. 1989; 50:68-71. | PubMed

15. Goldsmith LT, Lust $G$ and Steinetz BG. Transmission of relaxin from lactating bitches to their offspring via suckling. Biol Reprod. 1994; 50:258-65. | Article | PubMed

16. Steinetz BG, Bullesbach EE, Goldsmith LT, Schwabe C and Lust G. Use of synthetic canine relaxin to develop a rapid homologous radioimmunoassay. Biol Reprod. 1996; 54:1252-60. | Article | PubMed

17. Carlson DA and Gese EM. Relaxin as a diagnostic tool for pregnancy in the coyote (Canis latrans). Anim Reprod Sci. 2007; 101:304-12. | Article I PubMed

18. Bauman JE, Clifford DL and Asa CS. Pregnancy diagnosis in wild canids using a commercially available relaxin assay. Zoo Biol. 2008; 27:406-13. | Article | PubMed

19. DiGangi BA, Griffin B, Levy JK, Smith BF and Baker HJ. Use of a commercially available relaxin test for detection of pregnancy in cats. $J$ Am Vet Med Assoc. 2010; 237:1267-74. | Article | PubMed

20. Bullesbach EE and Schwabe $C$. Total synthesis of human relaxin and human relaxin derivatives by solid-phase peptide synthesis and sitedirected chain combination. J Biol Chem. 1991; 266:10754-61. | Article I PubMed

21. Hossain MA, Lin F, Zhang S, Ferraro T, Bathgate RAD, Tregear GW and Wade JD. Regioselective disulfide solid phase synthesis, chemical characterization and in vitro receptor binding activity of equine relaxin. Int J Peptide Res Therap. 2006; 12:211-156. I Article

22. Samuel CS, Lin F, Hossain MA, Zhao C, Ferraro T, Bathgate RA, Tregear GW and Wade JD. Improved chemical synthesis and demonstration of the relaxin receptor binding affinity and biological activity of mouse relaxin. Biochemistry. 2007; 46:5374-81. | Article | PubMed

23. Zhang S, Lin F, Hossain MA, Shabanpoor F, Tregear GW and Wade JD. Simultaneous post-cysteine S-acetomidomethyl (Acm) group removal quenching of iodine and isolation of peptide by one-step ether precipitation. Int J Peptide Res Therap. 2008; 14:301-5. | Article

24. Najbar LV, Craik DJ, Wade JD, Salvatore D and McLeish MJ. Conformational analysis of LYS(11-36), a peptide derived from the beta-sheet region of T4 lysozyme, in TFE and SDS. Biochemistry. 1997; 36:11525-33. | Article | PubMed
25. Shabanpoor F, Bathgate RA, Belgi A, Chan LJ, Nair VB, Wade JD and Hossain MA. Site-specific conjugation of a lanthanide chelator and its effects on the chemical synthesis and receptor binding affinity of human relaxin-2 hormone. Biochem Biophys Res Commun. 2012; 420:253-6. | Article I PubMed

26. Scott DJ, Layfield S, Yan Y, Sudo S, Hsueh AJ, Tregear GW and Bathgate RA. Characterization of novel splice variants of LGR7 and LGR8 reveals that receptor signaling is mediated by their unique low density lipoprotein class A modules. J Biol Chem. 2006; 281:34942-54. | Article | PubMed

27. Wade JD: Double-stranded cystine peptides. In Buchner J and Moroder L (Eds.), Oxidative Folding of Peptides and Proteins RSC Publishing, Cambridge, 2009, 345-366. |Book

28. Liu F, Luo EY, Flora DB and Mayer JP. Concise synthetic routes to human insulin. Org Lett. 2013; 15:960-3. | Article | PubMed

29. Rosengren KJ, Zhang S, Lin F, Daly NL, Scott DJ, Hughes RA, Bathgate RA, Craik DJ and Wade JD. Solution structure and characterization of the LGR8 receptor binding surface of insulin-like peptide 3. J Biol Chem. 2006; 281:28287-95. | Article | PubMed

30. Akhter Hossain M, Bathgate RA, Kong CK, Shabanpoor F, Zhang S, Haugaard-Jonsson LM, Rosengren KJ, Tregear GW and Wade JD. Synthesis, conformation, and activity of human insulin-like peptide 5 (INSL5). Chembiochem. 2008; 9:1816-22. | Article | PubMed Abstract | PubMed Full Text.

31. Hossain MA, Belgi A, Lin F, Zhang S, Shabanpoor F, Chan L, Belyea C, Truong HT, Blair AR, Andrikopoulos S, Tregear GW and Wade JD. Use of a temporary "solubilizing" peptide tag for the Fmoc solid-phase synthesis of human insulin glargine via use of regioselective disulfide bond formation. Bioconjug Chem. 2009; 20:1390-6. | Article | PubMed

32. Hossain MA, Rosengren KJ, Haugaard-Jonsson LM, Zhang S, Layfield S, Ferraro T, Daly NL, Tregear GW, Wade JD and Bathgate RA. The A-chain of human relaxin family peptides has distinct roles in the binding and activation of the different relaxin family peptide receptors. J Biol Chem. 2008; 283:17287-97. | Article | PubMed

33. Hossain MA, Wade JD and Bathgate RA. Chimeric relaxin peptides highlight the role of the A-chain in the function of $\mathrm{H} 2$ relaxin. Peptides. 2012; 35:102-6. | Article | PubMed

34. Tickler AK, Clippingdale $A B$ and Wade JD. Amyloid-beta as a "difficult sequence" in solid phase peptide synthesis. Protein Pept Lett. 2004; 11:377-84. | Article | PubMed

35. Scholtz JM, Qian H, York EJ, Stewart JM and Baldwin RL. Parameters of helix-coil transition theory for alanine-based peptides of varying chain lengths in water. Biopolymers. 1991; 31:1463-70. | Article | PubMed

\section{Citation:}

Lin F, Tailhades J, Chan LJ, Bathgate RA, Hossain MA and Wade JD. Preparation of canine relaxin by Fmocsolid phase synthesis and regioselective disulfide bond formation within the A- and B-chains. Bio Chem Comp. 2013; 1:4. http://dx.doi.org/10.7243/2052-9341-1-4 